УДК 616-001.37-089.844

DOI 10.11603/2414-4533.2019.4.10718

(с). В. ШАПРИНСЬКИЙ

Вінницький національний медичний університет імені М. І. Пирогова

\title{
Сучасні методи реконструкції стравоходу при його резекції та екстирпації
}

\begin{abstract}
Мета роботи: у статті подано підвищення ефективності хірургічного лікування хворих на рубцеві стриктури стравоходу шляхом вибору оптимального способу реконструкції стравоходу при його резекції та екстирпації.

Матеріали і методи. Дослідження включало результати обстеження та лікування 177 хворих з рубцевими стриктурами стравоходу різної етіології, які підлягали реконструкції стравоходу. Для прогнозу виникнення ускладнень використовували метод логістичної регресії. При високому ризику розвитку ускладнень (більше 70 \%) хворі підлягали тільки мініінвазивним методам лікування, а саме: стентуванню чи гастростомії та інтенсивній терапії у відділенні реанімації. При середньому ступені ризику розвитку ускладнень (40-70 \%) хворі підлягали інтенсивній інфузійній терапії перед подальшою езофагопластикою в умовах відділення реанімації. При низькому ступені ризику розвитку ускладнень (менше 40 \%) хворі підлягали реконструктивній операції з попереднім проведенням передопераційної підготовки у хірургічному відділенні.

Результати досліджень та їх обговорення. Розроблений алгоритм вибору методу реконструкції стравоходу полягав у тому, що при протяжності стриктури менш ніж 3,0 см виконували пластику власними тканинами. При протяжності стриктури більш ніж 3,0 см та наявності раку стравоходу проводили езофагопластику автотрансплантатом залежно від її локалізації. При високій стриктурі виконували езофагопластику товстою кишкою за розробленою методикою клініки, а також у випадку неможливості використання шлунка. При серединній і низькій стриктурі стравоходу проводили езофагопластику шлунковою трубкою з запропонованим способом її подовження, при неможливості її виконання виконували езофагопластику товстою кишкою. При неможливості використання як трансплантата шлунка та товстої кишки була розроблена езофагопластика ілеоцекальним сегментом. Застосування запропонованого алгоритму вибору методу реконструкції стравоходу дозволило достовірно знизити рівень ускладнень із боку стравохідно-органних анастомозів, скоротити тривалість перебування хворих у стаціонарі, тривалість післяопераційного періоду та знизити післяопераційну летальність з 6,0 до 2,6%.
\end{abstract}

Ключові слова: стриктура стравоходу; лікувальна тактика; метод реконструкції стравоходу.

Постановка проблеми і аналіз останніх досліджень та публікацій. Реконструктивний етап оперативних втручань після виконання резекції стравоходу чи його екстирпації належить до категорії підвищеної складності. Це зумовлено анатомо-фізіологічними особливостями будови стравоходу, його розташуванням, відсутністю серозної оболонки, особливостями сегментарного кровопостачання та ін. [1, 3, 4, 6]. Існують різноманітні способи реконструкції стравоходу: власними тканинами, з використанням шлунка, сегмента тонкої кишки, сегмента товстої кишки. У світовій літературі не існує єдиної думки щодо обрання того чи іншого методу реконструкції стравоходу. Високі показники летальності та післяопераційних ускладнень при реконструкції стравоходу стримують багатьох хірургів від їх виконання. Так, летальність може сягати $15 \%$, а неспроможність швів та стриктури анастомозів до $25 \%$ [2, 5].

Мета роботи - підвищити ефективність хірургічного лікування хворих на рубцеві стриктури стравоходу шляхом вибору оптимального способу реконструкції стравоходу при його резекції та екстирпації.
Матеріали і методи. Дослідження включало результати обстеження та лікування 177 хворих із рубцевими стриктурами стравоходу різної етіології, які підлягали реконструкції стравоходу. Пацієнти перебували на лікуванні у відділенні захворювань стравоходу та шлунково-кишкового тракту ДУ “Інститут загальної та невідкладної хірургії ім. В. Т. Зайцева НАМН України” (107 пацієнтів), а також у відділенні торакальної хірургії Вінницької обласної клінічної лікарні ім. М. І. Пирогова (70 пацієнтів) з 2005 до 2019 р. Більшість пацієнтів була працездатного віку (від 45 до 74 років) та у $70 \%$ - чоловіки. За етіологією стриктури розподілялись на післяопікові - у 64, післяопераційні у 32 пацієнтів, пептичні - у 16 на фоні гастроезофагеальної рефлюксної хвороби та рак стравоходу - у 65 пацієнтів.

Для прогнозу виникнення ускладнень використовували метод логістичної регресії. Всього обстежено 157 пацієнтів, із них з післяопераційними ускладненнями (випадки) 82, без післяопераційних ускладнень (контроль) 75. Згідно з розробленою прогностичною моделлю встановлено, що ризик виникнення післяопераційних ускладнень достовірно зростає при наявності техніч- 
них труднощів під час операцій, коефіцієнт моделі = 4,1399 з p=0,0083; цукрового діабету, коефіцієнт моделі = 3,2766 з p=0,0693; рівня альбумінів плазми крові менше ніж 25 г/л, коефіцієнт моделі $=3,2932$ з p=0,0224. Після прогнозування виникнення ускладнень ведення хворих проводили згідно з розробленим лікувальним алгоритмом. Лікувальний алгоритм полягав у тому, що при високому ризику розвитку ускладнень (вище ніж 70 \%), хворі підлягали тільки мініінвазивним методам лікування, а саме: стентуванню чи гастростомії та інтенсивній терапії у відділенні реанімації та інтенсивної терапії. При середньому ступені ризику розвитку ускладнень (40-70 \%) хворі підлягали інтенсивній інфузійній терапії перед подальшою езофагопластикою в умовах відділення реанімації та інтенсивної терапії. При низькому ступені ризику розвитку ускладнень (до 40 \%) хворі підлягали реконструктивній операції з попереднім проведенням передопераційної підготовки у хірургічному відділенні.

Алгоритм вибору методу реконструкції стравоходу при його резекції та екстирпації зображений на рисунку 1. Реконструкція стравоходу 3 використаннням сегмента ободової кишки була виконана у 54 хворих, з яких у 44 хворих - при післяопікових рубцевих стриктурах та у 10 - при ураженні онкопроцесом. Це були високі стриктури, а також випадки, коли неможливо було використати для реконструкції шлунок. Реконструкцію стравоходу товстою кишкою виконували 3 ізоперистальтичним ретростернальним розміщенням створеного трансплантата, який являв частину висхідної, поперечно ободову і частину нисхідної ободової кишки. Як живильну ніжку зберігали ліву ободовокишкову артерію. Передопераційно 12 пацієнтам виконували рентгенендоваскулярну підготовку майбутнього товстокишкового трансплантата шляхом проведення під час ангіографічного дослідження емболізації артеріальних гілок для адаптації основної живильної судини. Під час реконструктивно-відновної операції для визначення меж життєздатності трансплантата використовували розроблений пульсоксиметричний, оцінюючи показники сатурації кисню та частоту пульсу у створеному товстокишковому трансплантаті. Сформований трансплантат проводили у створеному загруднинному тунелі у 42 хворих та у 12 хворих проводили внтрішньоплеврально. Використовували розроблений спосіб формування дистального антирефлюксного кологастроанастомозу шляхом створення губок зі стінки товстокишкового трансплантата. Шийний, проксимальний анастомоз, у 12 хворих формували
3 використанням запропонованого способу формування апаратного, циркулярного, степлерного шийного езофаго-органного анастомозу.

Реконструкція стравоходу 3 використанням шлунка була проведена у 67 хворих, з яких - у 10 хворих причинами були післяопікові стриктури, у 5 - післяопераційні рубцеві стриктури, у 15 - пептичні стриктури та у 37 - злоякісне ураження. Це були випадки ураження стриктурою середньогрудного, нижньогрудного та абдомінального відділів стравоходу, а також ситуації, коли неможливо було використати для реконструкції стравоходу ободову кишку. У клініці переважно виконували трансхіатальну екстирпацію стравоходу з пластикою шлунковою трубкою, сформованою $з$ великої кривини шлунка. Застосовували розроблений спосіб подовження шлункового трансплантата, а саме: розрізом до 3,0 см пересікали в поперечному напрямку з боку малої кривини пілоричний відділ шлунка, не розкриваючи слизову оболонку, розтягуали, потім зашиваючи у поздовжньому напрямку, та додатково мобілізували дванадцятипалу кишку за Кохером і клітковину навколо головки підшлункової залози.

У випадку неможливості використання для реконструкції стравоходу товстої кишки або шлунка як трансплантат використовували ілеоцекальний сегмент (див. рис. 1). Розроблена реконструкція стравоходу з використанням ілеоцекального сегмента була виконана у 13 хворих, з яких у 10 хворих причинами було злоякісне ураження (рак стравоходу), у 3 - післяопікові стриктури стравоходу, поєднані з опіком шлунка, коли останній неможливо було використати в обох випадках, та спостерігався розсипний тип кровопостачання товстої кишки та погано виражена основна артеріальна аркада. Як живильну ніжку використовували а. ileocolica, яка є надійною для забезпечення живлення ілеоцекального сегмента. При стриктурі верхньогрудного i середньогрудного відділу стравоходу вона є короткою, тому реконструкцію стравоходу виконували при збереженні кровопостачання за рахунок більш довгої а. colica media. Але при цьому використовували запропонований метод реваскуляризації шляхом формування судинних анастомозів між а. ileocolica 3 зовнішньою сонною артерією, що було виконано у 5 хворих.

У 19 випадках післяопераційного виникнення неспроможностей та стриктур езофаго-органних анастомозів (у віддаленому післяопераційному періоді) було проведене ендоскопічне стентування ділянки стравохідного анастомозу під рентгенологічним контролем в умовах рентген- 
стравоходу при иого резекци та екстирпаци

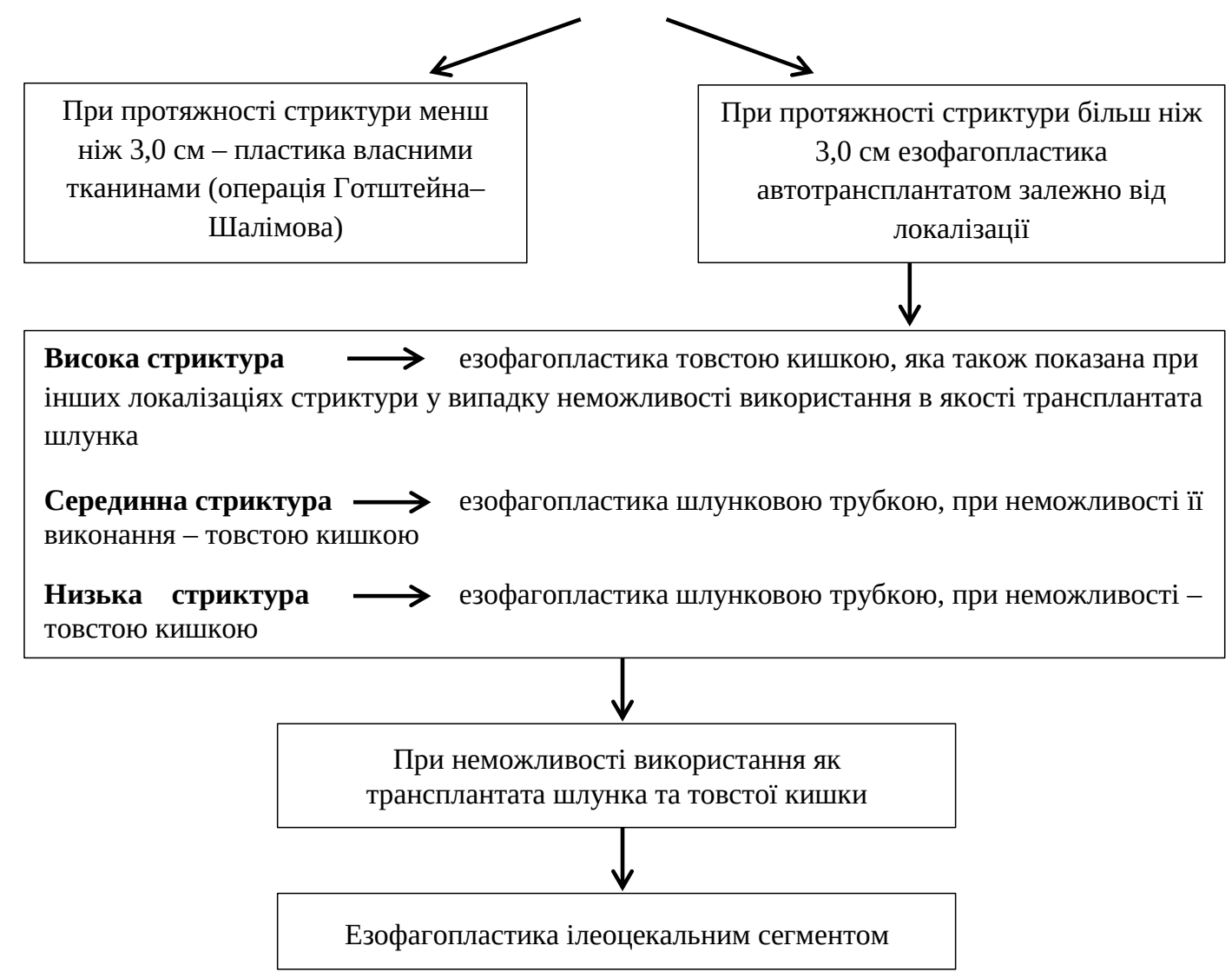

Рис. 1. Алгоритм вибору методу реконструкції стравоходу при його резекції та екстирпації.

операційної. 3 приводу неспроможності стравохідно-органного анастомозу було встановлено стенти, що саморозширюються, у дев'яти хворих, при розвиненій стриктурі стравохідно-органного анастомозу - у десяти хворих. Використовували нітінолові стенти з поліуретановим покриттям HANAROSTENT і антирефлюксним клапаном - у 17 та ULTRAFLEX з полімерним покриттям - у двох хворих.

Результати досліджень та їх обговорення. У групі порівняння в ранньому післяопераційному періоді неспроможності анастомозів у чотирьох хворих призвели до тяжких ускладнень: емпієми та медіастиніту, що стало причинами летальних наслідків. У десяти хворих неспроможності анастомозів ліквідували консервативно, а у чотирьох пацієнтів основної групи - шляхом стентування. Загалом неспроможність швів стравохідноорганного анастомозу виникла у 14 хворих групи порівняння (14,00 \%) і в 4 хворих основної групи (5,19 \%). Стриктури в основному спостерігались
3 боку шийного езофаго-органного анастомозу: у 20 хворих групи порівняння (20,00 \%) та у 8 хворих основної групи $(10,39 \%),(p<0,05)$.

Таким чином, застосування запропонованого алгоритму вибору оптимального методу реконструкції стравоходу при його резекції та екстирпації у хворих на рубцеві стриктури стравоходу дозволяє достовірно знизити рівень ускладнень 3 боку анастомозів $(\mathrm{p}<0,05)$, скоротити тривалість перебування хворих у стаціонарі з $(26,1 \pm 1,1)$ до $(22,0 \pm 0,5)$ ліжко-дня $(\mathrm{p}<0,001)$, тривалість післяопераційного періоду - $3(19,5 \pm 1,1)$ до $(15,2 \pm 0,7)$ ліжко-днів $(\mathrm{p}<0,01)$ та знизити післяопераційну летальність з 6,0 до 2,6 \%.

Висновки. 1. Хворі, які підлягають проведенню реконструктивної операції на стравоході, повинні бути всебічно обстежені з визначенням рівня рубцевої стриктури та операбельності при злоякісному ураженні з урахуванням даних СКТ та прогнозуванням ризику виникнення ускладнень згідно з запропонованим способом. 
Запропонований алгоритм вибору методу реконструкції стравоходу дозволяє здійснити пластику стравоходу найбільш оптимальним спосо- бом та достовірно знизити рівень як загальних, так і місцевих ускладнень та летальності.

\section{СПИСОК ЛІТЕРАТУРИ}

1. Багиров М. М. Применение тотальной и субтотальной эзофагопластики в лечении рубцового стеноза пищевода / М. М. Багиров, Р. И. Верещако // Клінічна хірургія. - 2008. - № 8. - С. 11-15.

2. Мовчан Б. Б. Пути улучшения результатов эзофагопластики / Б. Б. Мовчан // Клінічна хірургія. - 2007. - № 2-3. - С. 50.

3. Бойко В. В. Вибір живлячих судин при проведенні езофагопластики ілеоцекальним сегментом / В. В. Бойко, $€$. В. Шапринський // Вісник наукових досліджень. - 2016. № 3 (84). - С. 39-45.

4. The use of self-expanding silicone stents in esophagectomy strictures: less cost and more efficiency [електронний ресурс]
/ R. C. Martin, C. Woodall, R. Duvall, C. R. Scoggins // Ann. Thorac. Surg. - 2008. - Vol. 86, No. 2. - P. 436-440. [abstract PMID: 18640310]. - Access mode : www.ncbi.nih.gov.

5. Marshall M. B. Laparoscopic intragastric approach for gastroesophageal leiomyoma and cancer / M. B. Marshall, N. G. Haddad // J. Thorac. Cardiovasc. Surg. - 2015. - Vol. 149, No. 4. - P. 1210-1212.

6. Robot-assisted thoracoscopic esophagectomy with extensive mediastinal lymphadenectomy: experience with 114 consecutive patients with intrathoracic esophageal cancer / S. Y. Park, D. J. Kim, W. S. Yu, H. S. Jung // Dis. Esophagus. - 2016. Vol. 29, No. 4. - P. 326-332.

\section{REFFERENCES}

1. Bagirov, M.M., \& Vereshchako, R.I. (2008). Primenenie totalnoy $i$ subtotalnoy ezofagoplastiki $v$ lechenii rubtsovogo stenoza pishchevoda [Use of total and subtotal esophagoplasty in treatment of corrosive esophageal strictures]. Klinichna khirurgiya - Clinical Surgery, 8, 11-15 [in Russian].

2. Movchan, B.B. (2007). Puti uluchsheniya resultatov ezofagoplastiki [The ways of improvement of esophagoplasty results]. Klinichna khirurgiya - Clinical Surgery, 2-3, 50 [in Russian].

3. Boiko, V.V., \& Shaprynskyi, Ye.V.(2016). Vybir zhyvliachykh sudyn pry provedenni ezofahoplastyky ileotsekalnym sehmentom [The choice of feeding vessels during esophageal replacement by ileocecal segment]. Visnyk naukovykh doslidzhen - Bulletin of
Scientific Research, 3, 39-45 [in Ukrainian].

4. Martin, R.C., Woodall, C., Duvall, R., \& Scoggins, C.R. (2008). The use of self-expanding silicone stents in esophagectomy strictures: less cost and more efficiency. Ann. Thorac. Surg., 2, 436-440.

5. Marshall, M.B., \& Haddad, N.G. (2015). Laparoscopic intragastric approach for gastroesophageal leiomyoma and cancer. J. Thorac. Cardiovasc. Surg., 149 (4), 1210-1212.

6. Park, S.Y., Kim, D.J., Yu, W.S., \& Jung, H.S. (2016). Robotassisted thoracoscopic esophagectomy with extensive mediastinal lymphadenectomy: experience with 114 consecutive patients with intrathoracic esophageal cancer. Dis. Esophagus., 29 (4), 326332.

Отримано 28.10.2019

Електронна адреса для листування: evgensh20078@gmail.com.

\section{Y. V. SHAPRYNSKYI}

M. Pyrohov Vinnytsia National Medical University

\section{MODERN METHODS OF ESOPHAGEAL RECONSTRUCTION IN CASE OF ITS RESECTION AND EXTIRPATION}

The aim of the work: the article is devoted to the problem of improving the efficiency of surgical treatment in patients with corrosive strictures of the esophagus by choosing optimal esophageal reconstruction method in case of its resection and extirpation. Materials and Methods. The results of examination and treatment of 177 patients with corrosive esophageal strictures of various etiology were reviewed in the study. All patients underwent esophageal reconstruction. Logistic regression method was used to predict the development of complications. In high risk of complications (over $70 \%$ ), the patients underwent minimally invasive treatment. In average risk of complications (40-70\%), the patients underwent intensive infusion therapy prior to esophagoplasty at the intensive care unit. In low risk of complications (less than $40 \%$ ), the patients underwent reconstructive surgery with proper preoperative preparation at the surgical department.

Results and Discussion. The developed algorithm was the following: in the presence of strictures less than $3.0 \mathrm{~cm}$ in length, esophagoplasty using the patients' own tissues was carried out. The strictures of more than $3.0 \mathrm{~cm}$ in length and the presence of esophageal cancer were indications for esophagoplasty by autograft. In high strictures, colon esophagoplasty was performed according to the developed method of the clinic, as well as in cases of impossibility to use the stomach. In middle and low esophageal strictures, esophagoplasty was performed by gastric tube according to the proposed method; otherwise, colon esophagoplasty was performed. Esopha- 


\section{З ДОСВІДУ РОБОТИ}

goplasty by ileocecal segment was developed for cases when the stomach and the colon could not be used as a transplant. The use of proposed algorithm for the choice of esophageal reconstruction method has led to significant decrease in the level of complications associated with esophageal-organ anastomoses, duration of hospital stay, duration of postoperative period as well as postoperative mortality rate (from $6.0 \%$ to $2.6 \%$ ).

Key words: esophageal stricture; therapeutic approach; esophageal reconstruction method.

\section{Е. В. ШАПРИНСКИЙ}

Винницкий национальный медицинский университет имени Н. И. Пирогова

\section{СОВРЕМЕННЫЕ МЕТОДЫ РЕКОНСТРУКЦИИ ПИЩЕВОДА ПРИ ЕГО РЕЗЕКЦИИ И ЭКСТИРПАЦИИ}

Цель работы: статья посвящена повышению эффективности хирургического лечения больных с рубцовыми стриктурами пищевода путем выбора оптимального способа реконструкции пищевода при его резекции и экстирпации.

Материалы и методы. Исследование включало в себя результаты обследования и лечения 177 больных с рубцовыми стриктурами пищевода различной этиологии, которые подлежали реконструктивной операции. Для прогноза возникновения осложнений использовали метод логистической регрессии. При высоком риске развития осложнений (более 70 \%) больные подлежали только миниинвазивным методам лечения, а именно: стентированию или гастростомии и интенсивной терапии в отделении реанимации. При средней степени риска развития осложнений (40-70\%) больные подлежали интенсивной инфузионной терапии перед дальнейшей эзофагопластикой в условиях отделения реанимации. При низкой степени риска развития осложнений (менее 40 \%) больные подлежали реконструктивной операции с предварительным проведением предоперационной подготовки в хирургическом отделении.

Результаты исследований и их обсуждение. Разработанный алгоритм выбора метода реконструкции пищевода заключался в том, что при протяженности стриктуры меньше 3,0 см выполняли пластику собственными тканями. При протяженности стриктуры более 3,0 см и наличии рака пищевода проводили эзофагопластику аутотрансплантатом в зависимости от ее локализации. При высокой стриктуре выполняли эзофагопластику толстой кишкой по разработанной методике клиники, а также в случае невозможности использования желудка. При срединной и низкой стриктуре пищевода проводили эзофагопластику желудочной трубкой с предложенным способом ее удлинения, при невозможности ее выполнения выполняли эзофагопластику толстой кишкой. При невозможности использования в качестве трансплантата желудка и толстой кишки была разработана эзофагопластика илеоцекальным сегментом. Применение предложенного алгоритма выбора метода реконструкции пищевода позволило достоверно снизить уровень осложнений со стороны пищеводно-органных анастомозов, сократить длительность пребывания больных в стационаре, продолжительность послеоперационного периода и снизить послеоперационную летальность с 6,0 до 2,6\%.

Ключевые слова: стриктура пищевода; лечебная тактика; метод реконструкции пищевода. 